\title{
The User Experience (UX) Analysis of Self-Service Kiosk (SSK) in Waiting Time at Fast Food Restaurant Using User Experience (UX) Model
}

\author{
Nor Aziati Abdul Hamid ${ }^{1}$, Nor Hazana Abdullah ${ }^{2}$, Ng Seow Chian ${ }^{1^{*}}$ \\ ${ }^{1}$ Department of Production and Operations Management, Faculty of Technology Management and Business, \\ Universiti Tun Hussein Onn Malaysia, Batu Pahat, Johor, 86000, MALAYSIA \\ ${ }^{2}$ Department of Technology Management, Faculty of Technology Management and Business, \\ Universiti Tun Hussein Onn Malaysia, Batu Pahat, Johor, 86000, MALAYSIA \\ *Corresponding Author \\ DOI: https://doi.org/10.30880/jstard.2021.03.02.010 \\ Received 15 November 2021; Accepted 20 October 2021; Available online 15 December 2021
}

\begin{abstract}
Studies found that customer satisfaction is affected by customers' waiting time in fast food restaurants. With the introduction of self-service kiosks (SSK) at McDonald's, number of complaints about long waiting time has been rising. Hence, this research intends to identify the relationship between user experience (UX), perceived waiting time, and waiting environment towards customer satisfaction. Additionally, this research also determines the relationship between UX and waiting environment towards perceived waiting time as well as to investigate behavioural intention upon customer satisfaction and perceived waiting time. 161 survey questionnaires were collected at McDonald's Parit Raja. Findings reveal UX and waiting environment affect customer satisfaction, however, perceived waiting time showed no effect to customer satisfaction. While UX and waiting environment affect perceived waiting time, and lastly perceived waiting time and customer satisfaction affect behavioural intention. Nevertheless, sample size of this study was limited and not sufficient to represent the population. Future research should include more areas in Malaysia and adopt mixed research method which compares SSK and queuing system. This paper provides insight for service sector to better understand the determinants of customer satisfaction and behavioural intention after implementing SSK in fast food restaurant.
\end{abstract}

Keywords: User experience, waiting time, self-service kiosk, fast food restaurant

\section{Introduction}

Over the past decade, self-service technology (SST) has emerged in service industry [1] which replaced direct connection between purchaser and provider of the service. Business companies adopted SST to enhance operation quality, expertise, and effectiveness by providing customers an access to services through modern and convenient channels [2][3][4]. SST allowed customers to deliver services for themselves using technological innovation, most used technologies include automatic telling machines (ATMs), online banking services, and self-service kiosk (SSK). In food service industry, SST is expected to boost service quality whilst establishing new and positive customer experiences [5]. User experience (UX) was essential for fast food restaurants to win customers. It would be a better and more convenient experience for customers if they can quickly find information on the SSK without seeking help from the employees. UX has been widely accepted worldwide, however, there was no clear definition. Besides, UX evaluation is an urgent need because UX analysis determined the functions of SSK to attract more customers. In year 2017, McDonald's was the first food service industry that introduced SSK in Malaysia. Hence, this study intends to examine UX of SSK and how UX influences waiting time of using SSK at McDonald's. Customers' behavioural 
intention to use SSK upon customer satisfaction and perceived waiting time has also been investigated. Findings are expected to give better understanding on the relationship between UX and SSK in Malaysia context.

\subsection{Research Background}

Chen Jia Wai [6] defined fast food as food that was prepared in a standardized way and distributed quickly in a restaurant. Similarly, fast food refers to food that can be prepared and delivered as quickly and efficiently as possible [7][8]. Eating fast food has become a phenomenon in Malaysia due to human being's changing lifestyle and it gradually developed into a need for Malaysians [9]. The total number of fast food restaurants has increased drastically every year. In Malaysia, approximately there are 6000 franchise outlets of food and beverages dominate the market that valued at $\$ 493$ million (RM1.8 billion). Around the globe, among ten most popular fast-food brands include McDonald's, Kentucky Fried Chicken (KFC), Pizza Hut and Domino's Pizza [10]. Among those fast-food restaurants, McDonald and KFC are among the top restaurant preferred by Malaysian. This is correlate with the top choice of fast-food menu such as fried chicken, fries, and burgers. Back on $29^{\text {th }}$ April 1982, the first McDonald's in Malaysia was opened at the most strategic location during that time - Jalan Bukit Bintang, Kuala Lumpur. McDonald's Malaysia has also crowned as the country's first restaurant with the highest Muslim community [11]. As of year 2021, there were $300 \mathrm{McDonald's}$ restaurants nationwide. McDonald franchise business also embark in the technology innovation to improve their operation excellence and reduce the manpower. The digitalization of McDonald operation can be seen with the implementation of food ordering system using either their mobile apps or by using self-service kiosk. Align with the main objectives of the study, McDonald was selected for the current study.

\subsection{Problem Statement}

Traditional method of ordering systems often leads to human errors and service failures, for instance, language barriers or misspelling of orders, and long waiting hours during peak hours [12][13][14]. Hence, alternative technologies such as SSK can be used by customers themselves instead of waiting in long queue for staff's service [13][15][16].

Shortly after McDonald's rolled out SSK in Hong Kong, Singapore, and the surrounding market, SSK was finally brought to Malaysia's Bukit Bintang branch and Bangsar Telawi branch [17]. Out of 300 McDonald's restaurants in Malaysia, 191 outlets were equipped with SSK [18]. However, limited studies showed the experiences of customers with SSK. A study conducted (2019) [19] interviewing 16 person of Generation X whose age between 18-24 years old about their experience and views of using SSK in McDonald's restaurant. Findings revealed that SSK improved efficiency and it provided more time for menu selection with detailed and clearer information when it came to custom meals selection. Nevertheless, by using SSK, customers have a sense of authorization which may lead to longer waiting time as they have free time to consider when choosing a meal.

In Malaysia context, a user based on his own experience and observation, discovered five problems which affect user experience while using SSK at McDonald's restaurant Malaysia [20]. His first and second concern was about the interface of SSK as it was not user friendly, and instruction was not clear enough for food selection and customization of a meal. Obviously, this issue is critical as customers may require more time to select their meal and causing a queue to use SSK. The next problem was about payment system which he commented to be slowing down the ordering process because of misleading order number and "pay at counter" option seemed to be unnecessary since SSK provided cashless transaction by using credit or debit card. The fourth problem he encountered was regarding the number calling system during food collection because incorrect number was shown on the screen and staff were calling out order numbers for food collection which may cause mishearing issue. Lastly, it was confusing for customer to get a table number plate and insert the number back to the system after selecting checkout on the system. 5 problems listed by [20] above indicated the possibility of leaving customer a poor impression and experience while using SSK. Unexpectedly, his complaint brought attention to HUGE Consultancy who was McDonald's Global UX Design partner that focus on designing web, mobile app and in-restaurant touchpoints [21]. The company requested [20] to present his interface design and eventually the company implemented a few components suggested by the author. This incident clearly revealed the importance of user experience in adopting SSK. In another study, [22] found that customers are likely to accept SST if they think usage of the technology is a good option, enjoyable to use, and easy to use. On the other hand, [23] stated that if customers have difficulty in adopting the technology, their acceptance towards SST would be slow. So far, however, there has been little discussion about UX of SSK and its effect on customer satisfaction and behavioural intention.

In fast food service industry, service waiting time was a key performance indicator. Therefore, the major objectives of this study were to investigate the relationship between user experience, perceived waiting time, waiting environment and customer satisfaction. Additionally, previous researchers believes that consumer continuity should be used as a measuring tool to access technology's progress rate because it makes customers continue to use the technology when they find it efficient and effective [16][24]. Hence, this study also explores behavioural intention upon customer satisfaction and perceived waiting time. 


\section{Literature Review}

\subsection{Self-Service Kiosk (SSK)}

Self-service kiosk (SSK), which also known as interactive kiosk, was defined as a small independent structure used to display information or facilitate operations [25]. SSK provided by McDonald's is a device with large touch screen area that allow customers to order foods, customize their meals, and pay for their bill without interacting with staffs. Even though technology has transformed food service industry in Malaysia over the years, usage of SSK or digital ordering were still lacking in the industry [26] due to high implementation costs. In fact, this technology helps to ease financial pressure of a restaurant in the long run [27]. Recently, SSK has gradually turning into a convenient tool to resolve uncertainties in the new service setting and growing customer demand, especially by fast food chains such as McDonald's.

\subsection{User Experience (UX)}

[28][29] describes user experience (UX) as the overall experience of the feelings (emotions and thoughts), responses and behaviours generated among consumers by the direct or indirect use of systems, products, information or services. UX can be subjective in nature, and it continuously transformed over time corresponding to changes in the environment during usage. When designing a product or service, UX was an essential factor to consider. Human Computer Interaction (HCI) has been using user experience as primary concept for more than an era [31]. Similarly, [30] stated that user experience held an important position in various disciplines, especially design. Besides, UX has been believed to be the contributing factor to brand equity [32] and customers' frequency of use [31]. Thus, user experience was discussed in this study to understand the nature of SSK, to explore and identify general factors that should be considered when designing SSK.

\subsection{User Experience Questionnaire (UEQ)}

User experience questionnaire (UEQ) provided a set of quick assessment questions containing the best overall impression of UX. Using this questionnaire, users can convey their thoughts, perceptions and attitudes in a very clear and straightforward way while experiencing the product or service under investigation [33]. UEQ primarily adopted hedonic and pragmatic quality perception models. Therefore, UX was characterized as a context that covered perceived pragmatic (PQ) and hedonic quality (HQ) of user and general product evaluation [34]. According to [35], data collected using UEQ does not provide any information regarding the reasons of refusing or accepting the product or service under investigation. UEQ being used in this study consists of 6 scales with 26 items as shown in Table 1.

Table 1 - The user experience questionnaire (UEQ) 6 scales and 26 items

\begin{tabular}{ll}
\hline Scale & $\begin{array}{c}\text { Items } \\
\text { Attractiveness: }\end{array}$ \\
$\begin{array}{l}\text { General impression towards the product. Do users like or } \\
\text { dislike the product? This scale was a pure valence } \\
\text { dimension. }\end{array}$ & $\begin{array}{c}\text { Annoying/enjoyable, good/bad, } \\
\text { unlikable/pleasing, } \\
\text { unpleasant/pleasant, } \\
\text { attractive/unattractive, } \\
\text { friendly/unfriendly. }\end{array}$ \\
$\begin{array}{l}\text { Efficiency: } \\
\text { Was it possible to use the product fast and efficiently? Does } \\
\text { the user interface look organized? }\end{array}$ & $\begin{array}{c}\text { Fast/slow, inefficient/efficient, } \\
\text { impractical/practical, } \\
\text { organized/cluttered. }\end{array}$ \\
$\begin{array}{l}\text { Perspicuity: } \\
\text { Was it easy to understand how to use the product? Was it }\end{array}$ & $\begin{array}{c}\text { Not understandable/understandable, } \\
\text { easy to learn/difficult to learn, } \\
\text { complicated/easy, clear/confusing. }\end{array}$ \\
$\begin{array}{l}\text { Dependability: } \\
\text { Does the user feel in control of the interaction? Was the } \\
\text { interaction with the product secure and predictable? }\end{array}$ & $\begin{array}{c}\text { Unpredictable/predictable, } \\
\text { obstructive/supportive, secure/not } \\
\text { secure, meets expectations/does not } \\
\text { meet expectations. }\end{array}$ \\
$\begin{array}{l}\text { Stimulation: } \\
\text { Was it interesting and exciting to use the product? Does the } \\
\text { user feel motivated to further use the product? } \\
\text { Novelty: }\end{array}$ & $\begin{array}{c}\text { Valuable/inferior, boring/exciting, not } \\
\text { interesting/interesting, motivating } \\
\text { /demotivating }\end{array}$ \\
$\begin{array}{l}\text { Was the design of the product innovative and creative? Does } \\
\text { the product grab the attention of users? }\end{array}$ & $\begin{array}{r}\text { Creative/dull, inventive/conventional, } \\
\text { usual/leading edge, conservative } \\
\text { /innovative }\end{array}$ \\
\hline
\end{tabular}

Items listed in the questionnaire using semantic differential 7 points rating scale whereby each item consisted of a pair of terms with opposite meanings. As of today, UEQ provided more than 30 languages including Malay, Chinese, 
English, etc. [36] to fulfil different needs because participants were encouraged to fill out semantic differential survey questions in their native language. Applying UEQ was rather easy, respondents usually required only 3-5 minutes to understand the instructions and answer the questions [37].

\subsection{Waiting Environment}

Waiting environment related to physical design aspect such as architecture, layout, and lighting to create attractive waiting area in terms of comfort, spaciousness, or atmosphere and explicit distraction aspect such as television and reading material [38]. [39] stated that a pleasant waiting environment was undoubtedly one of the easiest and most effective ways to improve customers' evaluation of the wait and satisfaction with the service because it acted as a mood inducer. In an investigation into service environment on perceived waiting time and emotions at fast-food chain in Taiwan, [40] discovered that design elements of the waiting environment such as effects of colour and spatial layout improved experience of waiting customer.

\subsection{Perceived Waiting Time}

Perceived waiting time indicates the duration of waiting time estimated by customers [41]. [42] considered time to be a scarce resource that should be spent carefully, because time was both money and business, hence time are often viewed as a crucial aspect to increase productivity (input equals output) by both customers and providers. The customers' perception of the overall 'service experience' will be affected when the actual waiting time varies from the perceived waiting time. Furthermore, [43] found that perceived waiting time certainly had effect on customer satisfaction especially during unoccupied time. To examine the adoption of SSK, this study intends to identify whether user experience and waiting environment influence customers' perceived waiting time.

\subsection{Customer Satisfaction}

Churchill \& Surprenant [44] and [45] described satisfaction as the results of using a product or service comparing to the anticipated outcomes. For decades, customer satisfaction had held a key position in marketing to determine customer's post-purchase experience, for instance, brand loyalty, repeat purchase, and attitude change. [46] suggested that customer satisfaction strongly contributed to business profits and loyal customers. In the adoption of SSK, [47] revealed ease of use and the delivery speed positively affected customer satisfaction, while customer satisfaction also positively affected future willingness to use SSK. Seeing the significance of customer satisfaction in marketing aspect, this study aims to explore whether UX, perceived waiting time, and waiting environment affect customer satisfaction after implementing SSK at McDonald's outlets.

\subsection{Behavioural Intention}

Ahmed [48] stressed the importance of monitoring behavioral intention because it signifies actual purchase. He also indicates that due to the strong relationship between behavioral intention and actual consumer buying behavior, behavioral intention is considered as one of the most important concepts in marketing literature. A study by [49] implied that favorable behavioral intentions are associated with the ability of a service provider to make customer praise their service provided positively, to give recommendations to other customers, to stay faithful to the company and to increase spending or go for premiums price willingly with the company. Thus, behavioural intention was investigated to find out its relationship with perceived waiting time and customer satisfaction.

\subsection{Research Framework and Hypotheses}

This research focused on the user experience (UX) analysis (Fig. 1) shows that the framework of user experience (UX) on self-service kiosk (SSK) in waiting time at McDonalds' Parit Raja. There are four objectives in this study, which are:

- To determine the influence of user experience (UX) and perceived waiting time on customer satisfaction.

- To determine the influence of user experience (UX) and waiting environment on perceived waiting time.

- To explore whether waiting environments have a relation on customer satisfaction.

- To investigate the behavioural intention upon customer satisfaction and perceived waiting time.

While these following hypotheses were constructed to achieve objectives above:

- H1: User experience (UX) has a significant relationship with customer satisfaction.

- H2: Perceived waiting time has a significant relationship with customer satisfaction.

- H3: User experience (UX) has a significant relationship with the perceived waiting time.

- H4: Waiting environment has a significant relationship with perceived waiting time.

- H5: Waiting environment has a significant relationship with customer satisfaction.

- H6: Perceived waiting time has a significant relationship with behavioural intention. 
- H7: Customer satisfaction has a significant relationship with behavioural intention.

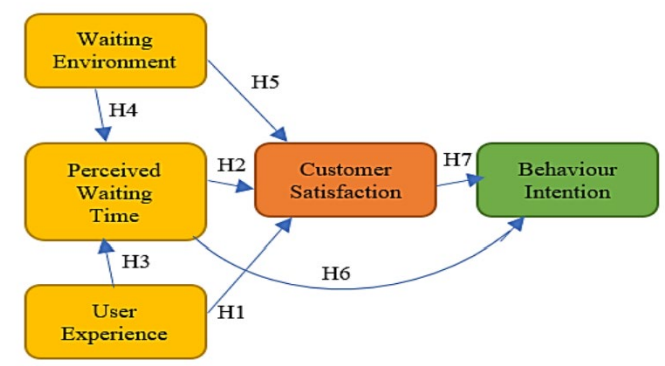

Fig. 1 - Conceptual framework of user experience (UX) analysis using self-service kiosk (SSK)

\section{Methodology}

\subsection{Research Design}

This study adopted quantitative research method whereby numerical data was collected by disseminating online survey questionnaire and analyzed using statistical analysis. To test hypotheses about the relationships between variables, quantitative method is more suitable to generalize results from the sample of target population. Target population of this study was the residents of Parit Raja because they were most likely the patrons of McDonald's restaurant in the area. Convenient sampling method which is a type of non-probability sampling technique was used to collect data for the reason of easy to use, cheap, and helps to improve research efficiency [50].

Survey questionnaire was formulated based on User Experience Questionnaire (UEQ) due to its conveniency and reliability. To further enhance questionnaire's reliability, pilot test with 35 questionnaires was conducted and the survey questionnaire was verified through Cronbach-Alpha reliability test. The questionnaire consists of three major parts, Part A, Part B, and Part C. Part A was to collect respondents' demographic information. Part B contained sub-section Part 1 to Part 9 to measure independent variables which include attractiveness, efficiency, perspicuity, dependability, stimulation, novelty, perceived waiting time, waiting environment, and customer satisfaction. Lastly, Part C constituted by 5 questions to assess one of the dependent variables - behavioural intention. Respondents were required to rate each question that consist of a pair of terms with opposite meanings on a 7-point semantic differential scale. As referred to [51], a scale of -3 to +3 was used to measure the agreement on all variables. Because of Covid- 19 pandemic, online survey by Google Form was circulated using online platforms such as Facebook, WhatsApp, and WeChat to prevent direct contact with respondents. Residents of Parit Raja who had experience in using SSK were invited to participated in this study. A total of 161 dataset was collected and analysed.

\subsection{Data Analysis}

Both descriptive analysis and inferential analysis was conducted to understand the relationships between research variables. Completed and finalized 161 dataset undergone descriptive analysis via IBM SPSS Statistic Version 26 software to describe respondents' demographic background and to measure data normality. Next, dataset was proceeded with inferential analysis which we used SmartPLS software to run partial least squares structural equation modelling (PLS-SEM) in this study. As referred to [50], structural equation modelling was used to test research hypotheses and he suggested researcher should select PLS-SEM if data distribution is not normally distributed.

\section{Results}

\subsection{Descriptive Statistics}

Table 2 displays demographic information about 161 respondents who took part in the survey. Among the respondents, 62 were male and 99 were female. More than half of the respondents were Chinese, which is 108 persons (67.1\%), followed by $42(25.1 \%)$ Malays, 5 (3.1\%) Indians, and $6(3.7 \%)$ persons from other races. $137(85.1 \%)$ respondents were between 21 to 25 years old, $14(8.7 \%)$ persons between 26 to 30 years old, $4(2.5 \%)$ of them age 41 and above, $3(1.9 \%)$ of them age 20 and below, $2(1.2 \%)$ respondents between 36 to 40 years old, and lastly only 1 $(0.6 \%)$ respondent age between 31 to 35 . Reason that majority of the respondents age between 21 to 25 was because Universiti Tun Hussein Onn was in Parit Raja, which justified those 125 (77.6\%) respondents were students. While, 23 $(14.3 \%)$ respondents were full time employment, $8(5 \%)$ were unemployed, and $5(3.1 \%)$ were part time employment. $66(41 \%)$ of the respondents claimed that they visit McDonald's restaurant once a month, 61 (37.9\%) persons go to McDonald's once within several month, 31 of them go there weekly, and 3 of them never been to McDonald's. Finally, 
150 persons that constituted to $93.2 \%$ of the respondents used McDonald's Kiosk System before, only 9 (5.6\%) persons haven't used the kiosk system, and 2 (1.2\%) persons might use the kiosk system before.

Table 2 - Respondents' demographic information

\begin{tabular}{|c|c|c|c|}
\hline Question & Option & Frequency & Percent (\%) \\
\hline \multirow[t]{3}{*}{ Gender } & Male & 62 & 38.5 \\
\hline & Female & 99 & 61.5 \\
\hline & Total & 161 & 100 \\
\hline \multirow[t]{5}{*}{ Race } & Malay & 42 & 26.1 \\
\hline & Chinese & 108 & 67.1 \\
\hline & Indian & 5 & 3.1 \\
\hline & Others & 6 & 3.7 \\
\hline & Total & 161 & 100 \\
\hline \multirow[t]{7}{*}{ Age Group } & 20 and below & 3 & 1.9 \\
\hline & $21-25$ & 137 & 85.1 \\
\hline & $26-30$ & 14 & 8.7 \\
\hline & $31-35$ & 1 & 0.6 \\
\hline & $36-40$ & 2 & 1.2 \\
\hline & 41 and above & 4 & 2.5 \\
\hline & Total & 161 & 100 \\
\hline \multirow[t]{5}{*}{ Occupation } & Student & 125 & 77.6 \\
\hline & Full time employment & 23 & 14.3 \\
\hline & Part time employment & 5 & 3.1 \\
\hline & Unemployed & 8 & 5 \\
\hline & Total & 161 & 100 \\
\hline \multirow{5}{*}{$\begin{array}{l}\text { How often do you go to } \\
\text { McDonald's restaurants? }\end{array}$} & Weekly & 31 & 19.3 \\
\hline & Monthly & 66 & 41 \\
\hline & Once within several month & 61 & 37.9 \\
\hline & Never & 3 & 1.9 \\
\hline & Total & 161 & 100 \\
\hline \multirow{4}{*}{$\begin{array}{l}\text { Have you used McDonald's } \\
\text { Kiosk System before? }\end{array}$} & Yes & 150 & 93.2 \\
\hline & No & 9 & 5.6 \\
\hline & Maybe & 2 & 1.2 \\
\hline & Total & 161 & 100 \\
\hline
\end{tabular}

Secondly, descriptive analysis was performed to determine reliability of variables. Reliability was tested by checking Cronbach's Alpha value of each variable, values between 0.6 to 0.7 indicates an acceptable level of reliability, whereas values between 0.7 to 0.9 considered as satisfactory, while value above 0.9 shows the best reliability [52]. Table 3 displays the results of reliability test. All variable used in the questionnaire were reliable, achieving value of Cronbach's Alpha at least 0.813 for waiting environment and highest 0.969 for customer satisfaction.

Table 3 - Results of reliability test with Cronbach's Alpha values

\begin{tabular}{lc}
\hline Variable & Cronbach's Alpha \\
\hline Attractiveness & 0.954 \\
Efficiency & 0.926 \\
Perspicuity & 0.916 \\
Dependability & 0.870 \\
Stimulation & 0.895 \\
Novelty & 0.915 \\
User experience & 0.923
\end{tabular}




$\begin{array}{ll}\text { Perceived waiting time } & 0.917 \\ \text { Waiting environment } & 0.813 \\ \text { Customer satisfaction } & 0.969 \\ \text { Behavioural intention } & 0.968\end{array}$

Lastly, descriptive analysis was conducted to examine normality of data distribution. Testing of normality was essential for continuous data to decide whether to use parametric or non-parametric analysis method for hypotheses testing in the next step based on data normality state, measures of central tendency, and dispersion [53]. Table 4 indicates the results of normality test. Skewness of all variables were negatively skewed whereby user experience was highly skewed, perceived waiting time and waiting environment was approximately symmetric, and customer satisfaction and behavioural intention was moderately skewed. Whereas, in the consideration of z-value (between \pm 1.96 ), only perceived waiting time and waiting environment were normally distributed, the rest of the variables are out of required threshold. As a result of not normally distributed data, PLS-SEM was selected for inferential analysis to test research hypotheses.

Table 4 - Results of normality test

\begin{tabular}{lccc}
\hline Variable & Statistic & $\begin{array}{c}\text { Skewness } \\
\text { Std. Error }\end{array}$ & Z-value \\
\hline User experience & -2.724 & 0.191 & -14.241 \\
Perceived waiting time & -0.252 & 0.191 & -1.316 \\
Waiting environment & -0.339 & 0.191 & -1.772 \\
Customer satisfaction & -0.743 & 0.191 & -3.883 \\
Behaviour intention & -0.680 & 0.191 & -3.553 \\
\hline
\end{tabular}

\subsection{Assessment of Reflective Measurement Model}

Figure 2 illustrates the structural model in this study which was generated using SmartPLS software while Table 5 displays the results of reflective measurement models. First, in reflective measurement model, indicator loadings should be above 0.708 to provide acceptable item reliability showing construct explains above $50 \%$ of the indicator's variance [51]. However, indicator loadings of D1, S4, N1, N2, N3, N4 were lower than 0.708, N3 was the lowest loading with 0.58 , thus, N3 is deleted. Whereas the rest of the loadings which was between 0.605 to 0.964 retained in the study because they do not influence much on internal consistency reliability and convergent validity.

Secondly, internal consistency reliability should be evaluated by assessing value of composite reliability, Cronbach's Alpha, and Rho A. Higher value means higher reliability, in which, values between 0.6 and 0.7 are deemed as "acceptable for exploratory research", 0.7 to 0.9 indicated "satisfactory to good", while value above 0.95 should be prevented as it indicates items may be redundant [51][54]. For composite reliability, values fall between 0.889 to 0.975 , Meanwhile the value of Cronbach's Alpha is between 0.813 to 0.971 , and lastly Rho A value is between 0.824 and 0.972. all of them shows excellent internal consistency reliability with a few values slightly exceeded suggested ceiling.

Thirdly, convergent validity of each variable needs to be assessed to measure the variance of its items. In this case, average variance extracted (AVE) was evaluated and the values of each variable are between 0.59 and 0.887. AVE should be more than or equal to 0.5 so that the variable support at least $50 \%$ of items' variance [54]. Thus, all variables achieved the requirement.

Next, discriminant validity must be measured to identify whether a variable is empirically discrete from other constructs in the model. Discriminant validity can be evaluated by checking Fornell and Larcker Criterion [55] and heterotrait-monotrait (HTMT) [56] which are shown in Table 6 and Table 7 respectively. Values Fornell and Larcker are the square root of AVE, the values on the diagonal should be greater than the values on the off diagonal to achieve discriminant validity. For example, AVE of "perceived waiting time" is 0.712 , its square root is 0.844 , and this number is greater than the correlation values in the column and row of "perceived waiting time". Therefore, Fornell and Larcker Criterion is achieved when all latent variables show similar observation. Nonetheless, HTMT is proposed to make up the weakness of Fornell and Larcker. [57] suggested to have HTMT values lower than 0.90, results in Table 7 indicates all values range from 0.449 to 0.837 . Hence, discriminant validity is established. 


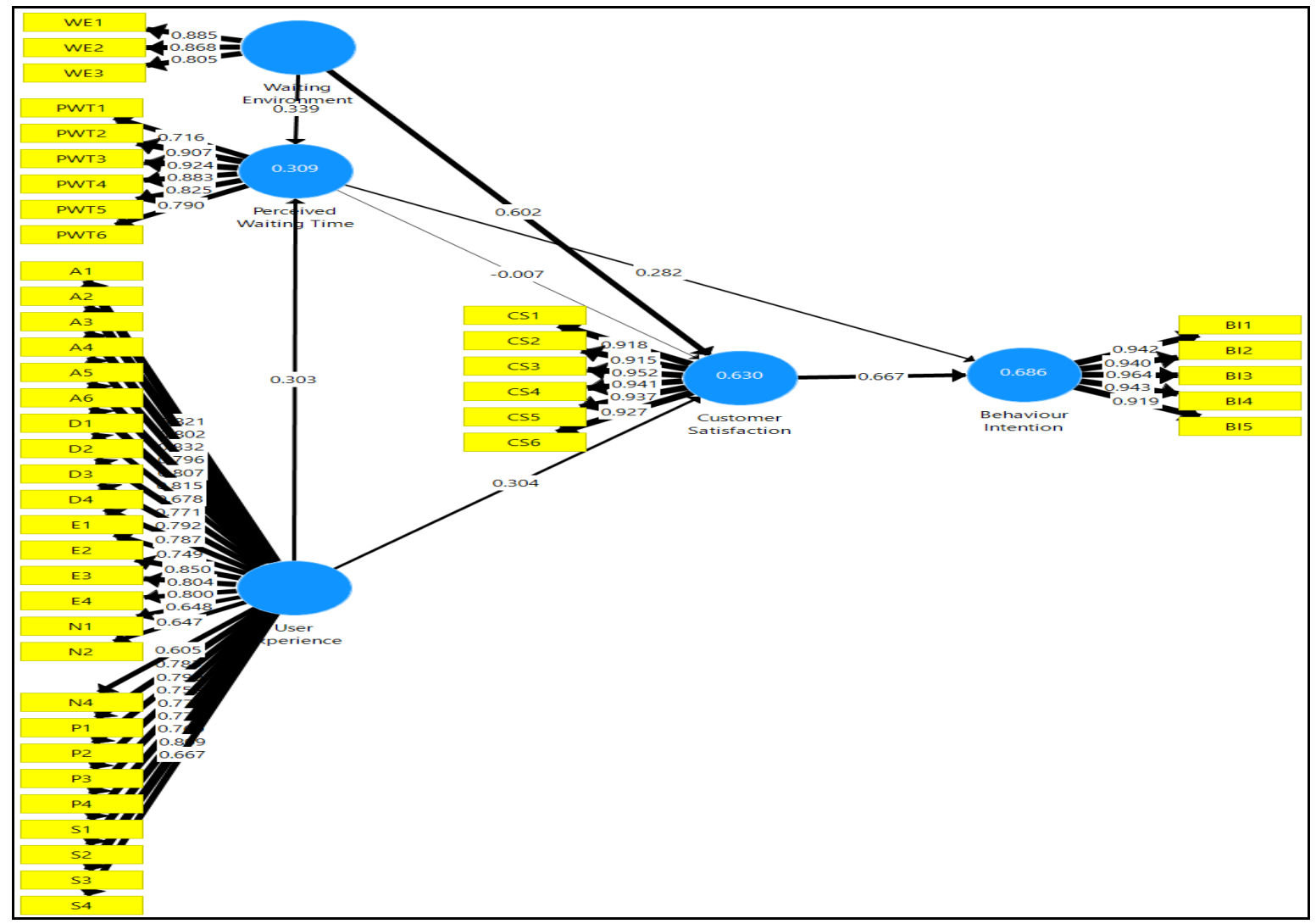

Fig. 2 - Structural model constructed using SmartPLS

Table 5 - Results of reliability and validity test from SmartPLS

\begin{tabular}{|c|c|c|c|c|c|c|}
\hline \multirow{3}{*}{$\begin{array}{c}\text { Latent } \\
\text { Variable }\end{array}$} & \multirow[t]{3}{*}{ Indicators } & \multirow{2}{*}{$\begin{array}{l}\text { Reflective } \\
\text { Indicator } \\
\text { Loadings }\end{array}$} & \multicolumn{3}{|c|}{ Internal Consistency Reliability } & \multirow{2}{*}{$\begin{array}{c}\text { Convergent } \\
\text { Validity } \\
\text { AVE }\end{array}$} \\
\hline & & & $\begin{array}{l}\text { Composite } \\
\text { Reliability }\end{array}$ & $\begin{array}{c}\text { Cronbach's } \\
\text { Alpha }\end{array}$ & Rho_A & \\
\hline & & $>0.6$ & $>0.6$ & $>0.5$ & $\geq 0.7$ to 0.95 & $>0.50$ \\
\hline User & A1 & 0.821 & 0.973 & 0.971 & 0.972 & 0.59 \\
\hline Experience & A2 & 0.802 & & & & \\
\hline & A3 & 0.832 & & & & \\
\hline & A4 & 0.796 & & & & \\
\hline & A5 & 0.807 & & & & \\
\hline & A6 & 0.815 & & & & \\
\hline & E1 & 0.749 & & & & \\
\hline & E2 & 0.85 & & & & \\
\hline & E3 & 0.804 & & & & \\
\hline & E4 & 0.8 & & & & \\
\hline & P1 & 0.783 & & & & \\
\hline & P2 & 0.799 & & & & \\
\hline & P3 & 0.759 & & & & \\
\hline & P4 & 0.777 & & & & \\
\hline & D1 & 0.678 & & & & \\
\hline & D2 & 0.771 & & & & \\
\hline & D3 & 0.792 & & & & \\
\hline & D4 & 0.787 & & & & \\
\hline & S1 & 0.776 & & & & \\
\hline & S2 & 0.76 & & & & \\
\hline & S3 & 0.809 & & & & \\
\hline & S4 & 0.667 & & & & \\
\hline & N1 & 0.648 & & & & \\
\hline & $\mathrm{N} 2$ & 0.647 & & & & \\
\hline & N4 & 0.605 & & & & \\
\hline
\end{tabular}




\begin{tabular}{|c|c|c|c|c|c|c|}
\hline Perceived & PWT1 & 0.716 & 0.936 & 0.918 & 0.93 & 0.712 \\
\hline \multirow{5}{*}{ Waiting Time } & PWT2 & 0.907 & & & & \\
\hline & PWT3 & 0.924 & & & & \\
\hline & PWT4 & 0.883 & & & & \\
\hline & PWT5 & 0.825 & & & & \\
\hline & PWT6 & 0.79 & & & & \\
\hline Waiting & WE1 & 0.885 & 0.889 & 0.813 & 0.824 & 0.728 \\
\hline \multirow{2}{*}{ Environment } & WE2 & 0.868 & & & & \\
\hline & WE3 & 0.805 & & & & \\
\hline Customer & $\mathrm{CS} 1$ & 0.918 & 0.975 & 0.97 & 0.97 & 0.868 \\
\hline \multirow[t]{5}{*}{ Satisfaction } & CS2 & 0.915 & & & & \\
\hline & CS3 & 0.952 & & & & \\
\hline & CS4 & 0.941 & & & & \\
\hline & CS5 & 0.937 & & & & \\
\hline & CS6 & 0.927 & & & & \\
\hline Behaviour & BI1 & 0.942 & 0.975 & 0.968 & 0.968 & 0.887 \\
\hline \multirow[t]{4}{*}{ Intention } & BI2 & 0.94 & & & & \\
\hline & BI3 & 0.964 & & & & \\
\hline & BI4 & 0.943 & & & & \\
\hline & BI5 & 0.919 & & & & \\
\hline
\end{tabular}

Table 6 - Results of Fornell and Larcker Criterion

\begin{tabular}{|c|c|c|c|c|c|}
\hline Latent Variable & $\begin{array}{l}\text { Behaviour } \\
\text { Intention }\end{array}$ & $\begin{array}{l}\text { Customer } \\
\text { Satisfaction }\end{array}$ & $\begin{array}{l}\text { Perceived } \\
\text { Waiting Time }\end{array}$ & $\begin{array}{l}\text { User } \\
\text { Experience }\end{array}$ & $\begin{array}{l}\text { Waiting } \\
\text { Environment }\end{array}$ \\
\hline $\begin{array}{l}\text { Behaviour Intention } \\
\text { Customer Satisfaction } \\
\text { Perceived Waiting Time }\end{array}$ & $\begin{array}{l}0.942 \\
0.788 \\
0.569\end{array}$ & $\begin{array}{l}0.932 \\
0.431\end{array}$ & 0.844 & & \\
\hline $\begin{array}{l}\text { User Experience } \\
\text { Waiting Environment }\end{array}$ & $\begin{array}{l}0.608 \\
0.688 \\
\end{array}$ & $\begin{array}{l}0.599 \\
0.749 \\
\end{array}$ & $\begin{array}{l}0.471 \\
0.489 \\
\end{array}$ & $\begin{array}{l}0.768 \\
0.496 \\
\end{array}$ & 0.853 \\
\hline \multicolumn{6}{|c|}{ Table 7 - Results of HTMT } \\
\hline Latent Variable & $\begin{array}{l}\text { Behaviour } \\
\text { Intention }\end{array}$ & $\begin{array}{l}\text { Customer } \\
\text { Satisfaction }\end{array}$ & $\begin{array}{l}\text { Perceived } \\
\text { Waiting Time }\end{array}$ & $\begin{array}{l}\text { User } \\
\text { Experience }\end{array}$ & $\begin{array}{l}\text { Waiting } \\
\text { Environmen }\end{array}$ \\
\hline \multicolumn{6}{|l|}{ Behaviour Intention } \\
\hline Customer Satisfaction & 0.813 & & & & \\
\hline Perceived Waiting Time & 0.598 & 0.449 & & & \\
\hline User Experience & 0.611 & 0.61 & 0.464 & & \\
\hline Waiting Environment & 0.77 & 0.837 & 0.559 & 0.545 & \\
\hline
\end{tabular}

\subsection{Assessment of Structural Model}

When the reflective measurement model is reliable and valid, the following step is to assess structural model. Standard evaluation criteria include assessing collinearity issues, significance of path coefficients, $\mathrm{R}^{2}, \mathrm{f}^{2}$ effect sizes, and predictive relevance $\mathrm{Q}^{2}$ effect sizes. Firstly, collinearity must be analyzed by examining variance inflation factor (VIF) values to ensure the structural relationships does not bias the regression results. It is recommended to have VIF values lower than 3 to prevent collinearity issue [54]. As shown in Table 8, inner VIF values are within 1.228 to 1.492 which means there is no collinearity issue with the variables.

Table 8 - Lateral collinearity assessment/ inner VIF value

\begin{tabular}{lccccc}
\hline & $\begin{array}{l}\text { Behaviour } \\
\text { Intention }\end{array}$ & $\begin{array}{l}\text { Customer } \\
\text { Satisfaction }\end{array}$ & $\begin{array}{l}\text { Perceived } \\
\text { Waiting Time }\end{array}$ & $\begin{array}{l}\text { User } \\
\text { Experience }\end{array}$ & $\begin{array}{l}\text { Waiting } \\
\text { Environment }\end{array}$ \\
\hline Behaviour Intention & & & & & \\
Customer Satisfaction & 1.228 & & & \\
Perceived Waiting Time & 1.228 & 1.447 & & \\
User Experience & & 1.459 & 1.326 & \\
Waiting Environment & & 1.492 & 1.326 & & \\
\hline
\end{tabular}


Secondly, relationship between variables can now be identify by running bootstrapping test with 5,000 subsamples using SmartPLS software. Relationship of variables are determined by the values of path coefficients and the values should be in between of +1 (strong positive relationship) and -1 (strong negative relationship). Besides, $T$ values and $\mathrm{P}$ values should be considered to decide acceptance or rejection of hypothesis. To accept a hypothesis, $T$ values should be higher than 1.96 and $\mathrm{P}$ values should be less than 0.05 at $5 \%$ significance level [54]. Table 9 indicates the results of path coefficient. It shows that all hypotheses are accepted at the significance level of 5\%, except Perceived Waiting Time $\rightarrow$ Customer Satisfaction (path coefficient $=-0.007 ; \mathrm{T}<1.96 ; \mathrm{P}>0.05$ ). H7 shows the strongest relationship $(0.667)$ and H5 shows scores second highest $(0.602)$, whereas H6 shows the weakest relationship $(0.282)$ as compared to other hypotheses.

Table 9 - Results of path coefficient

\begin{tabular}{clcccccc}
\hline Hypothesis & \multicolumn{1}{c}{ Relationship } & $\begin{array}{c}\text { Path } \\
\text { Coefficients }\end{array}$ & $\begin{array}{c}\text { T } \\
\text { Statistics }\end{array}$ & $\begin{array}{c}\text { P } \\
\text { Values }\end{array}$ & $\begin{array}{c}\text { Indication } \\
\text { 95\% Confidence } \\
\text { Interval }\end{array}$ \\
\hline H1 & $\begin{array}{l}\text { User Experience } \rightarrow \text { Customer } \\
\text { Satisfaction }\end{array}$ & 0.304 & 5.601 & 0 & Accepted & 0.205 & 0.416 \\
H2 & $\begin{array}{l}\text { Perceived Waiting Time } \rightarrow \\
\text { Customer Satisfaction }\end{array}$ & -0.007 & 0.082 & 0.934 & Rejected & -0.175 & 0.155 \\
H3 & $\begin{array}{l}\text { User Experience } \rightarrow \text { Perceived } \\
\text { Waiting Time }\end{array}$ & 0.303 & 5.346 & 0 & Accepted & 0.195 & 0.418 \\
H4 & $\begin{array}{l}\text { Waiting Environment } \rightarrow \\
\text { Perceived Waiting Time }\end{array}$ & 0.339 & 4.414 & 0 & Accepted & 0.181 & 0.48 \\
H5 & $\begin{array}{l}\text { Waiting Environment } \rightarrow \\
\text { Customer Satisfaction } \\
\text { Perceived Waiting Time } \rightarrow\end{array}$ & 0.602 & 11.626 & 0 & Accepted & 0.501 & 0.704 \\
H6 & $\begin{array}{l}\text { Behavioural Intention } \\
\text { Customer Satisfaction } \\
\text { Behavioural Intention }\end{array}$ & 0.282 & 4.419 & 0 & Accepted & 0.159 & 0.406 \\
H7 & & 12.041 & 0 & Accepted & 0.556 & 0.769 \\
\hline
\end{tabular}

Thirdly, coefficient of determination which denoted as $\mathrm{R}^{2}$ value of dependent variables should be examined to measure model's explanatory power by checking on the variance. Higher the value of $\mathrm{R}^{2}$, greater the explanatory power. $\mathrm{R}^{2}$ values of $0.75,0.50,0.25$ depict substantial, moderate, and weak respectively [57][58]. As shown in Table $10, \mathrm{R}^{2}$ value of behaviour intention and customer satisfaction is 0.686 and 0.630 which means moderate explanatory power. Whereas the value of $\mathrm{R}^{2}$ for perceived waiting time is 0.309 , indicating weak explanatory power.

Table 10 - Coefficient of determination, $\mathbf{R}^{2}$

\begin{tabular}{lll}
\hline Variable & $\mathbf{R}^{\mathbf{2}}$ & Indication \\
\hline Behaviour Intention & 0.686 & Moderate \\
Customer Satisfaction & 0.630 & Moderate \\
Perceived Waiting Time & 0.309 & Weak \\
\hline
\end{tabular}

Next, the fourth step is to measure $f^{2}$ effect size. As a guideline, values more than $0.02,0.15$, and 0.35 represent small, medium, and large effect sizes [59]. Table 11 displays the results of $f^{2}$ effect size for each hypothesis and its indication. Findings revealed H5 and H7 shows large effect size, H1 am H6 shows medium effect, H3 and H4 shows small effect, and lastly $\mathrm{H} 2$ shows no effect at all.

Table $11-f^{2}$ effect size

\begin{tabular}{llll}
\hline Hypothesis & Relationship & $\boldsymbol{f}^{\mathbf{2}}$ & Indication \\
\hline H1 & User Experience $\rightarrow$ Customer Satisfaction & 0.171 & Medium effect \\
H2 & Perceived Waiting Time $\rightarrow$ Customer Satisfaction & 0 & Negative effect \\
H3 & User Experience $\rightarrow$ Perceived Waiting Time & 0.1 & Small effect \\
H4 & Waiting Environment $\rightarrow$ Perceived Waiting Time & 0.125 & Small effect \\
H5 & Waiting Environment $\rightarrow$ Customer Satisfaction & 0.655 & Large effect \\
H6 & Perceived Waiting Time $\rightarrow$ Behavioural Intention & 0.206 & Medium effect \\
H7 & Customer Satisfaction $\rightarrow$ Behavioural Intention & 1.155 & Large effect \\
\hline
\end{tabular}


Lastly, $\mathrm{Q}^{2}$ should be calculated to assess PLS path model's predictive accuracy. As a rule of thumb, Q2 value greater than $0,0.25$, and 0.50 indicate small, medium, and large predictive relevance of the path model. Table 12 shows the outcomes of $\mathrm{Q}^{2}$ values for each endogenous or dependent variables. For behaviour intention and customer satisfaction, predictive accuracy is large, while perceived waiting's predictive accuracy is small.

Table 12 - Predictive accuracy, $\mathbf{Q}^{2}$

\begin{tabular}{lll}
\hline Endogenous Variables & $\mathbf{Q}^{\mathbf{2}}$ & Indication \\
\hline Behaviour Intention & 0.601 & Large \\
Customer Satisfaction & 0.542 & Large \\
Perceived Waiting Time & 0.209 & Small \\
\hline
\end{tabular}

\subsection{Goodness-of-fit}

Tenenhaus et al. [60] proposed a goodness-of-fit (GoF) index for PLS-SEM to measure combining effect size with convergent validity. However, [51] advised to use these measures cautiously because of the invalidity of GoF's usefulness empirically and conceptually. For GoF index, standardized root mean square residual (SRMR), normed fit index (NFI), and RMS theta should be assessed. As a guideline, SRMR should be lower than 0.08, NFI should be greater than 0.90 for acceptable fit, and RMS theta should be less than 0.12 to represent well-fitting model. Table 13 shows the results of GoF index, SRMR is 0.089 , NFI is 0.669 , and RMS theta is 0.175 which indicate poor fit of GoF.

Table 13 - Goodness-of-fit index

\begin{tabular}{ll}
\hline Index & Values \\
\hline SRMR & 0.089 \\
NFI & 0.669 \\
RMS theta & 0.175 \\
\hline
\end{tabular}

\section{Discussion}

The findings revealed that UX has positive significant relationship with customer satisfaction. This finding is consistent with [61] who used the same measurement items for UX to measure customer satisfaction. Surprisingly, perceived waiting time does not have significant relationship with customer satisfaction. This finding is differed from [43] and [62] whose studies proved perceived waiting time influence customer satisfaction. A further study with more focus on perceived waiting time and customer satisfaction is therefore suggested. Next, UX and waiting environment positively affects perceived waiting time. These results match those observed in earlier studies [43][63] [64]. As for waiting environment, similar finding was presented by [63][65]. However, the findings of the current study do not support the previous research by [66] who stated that waiting environment is not statistically significant to waiting time satisfaction. A possible explanation for this might be due to different culture in different country which may affect customer's behaviour [67]. Subsequently, perceived waiting time affects behavioural intention positively. This result is supported by [68] that purchase intention was influenced positively and significantly by service time. Finally, customer satisfaction presents strong positive relationship with behavioural intention. This outcome further supports the statement of [69] that customer satisfaction was an essential determinant of behavioural intention. On top of that, changes of customer satisfaction will cause significant effect on changes in their behavioural intentions [70].

\section{Conclusion}

This study discovered the relationships between UX, perceived waiting time, waiting environment, customer satisfaction, and behavioural intention to the usage of SSK at fast food restaurant in Malaysia. It is statistically proven that customer satisfaction strongly affected behevioural intention. Managers in the industry should focus on improving customer satisfaction to produce return customers or loyal customers. Secondly, waiting environment positively influenced customer satisfaction. Managers should invest in waiting environment so that customers can cope with boredom and be comfortable while waiting in line and ultimately it helps increasing customer satisfaction level. The generalisability of these results is subject to certain limitation. For instance, sample size does not adequately represent total population of SSK users at McDonald's Malaysia. Future research should include more areas in Malaysia to receive wider input from residents in Malaysia. Besides, future research might adopt mixed research method to conduct in-depth study to further examine relationships between variables in this study. 


\section{References}

[1] Leung, L. S. K., \& Matanda, M. J. (2013). The impact of basic human needs on the use of retailing self-service technologies: A study of self-determination theory. Journal of Retailing and Consumer Services, 20(6), 549-559.

[2] Kelly, P., Lawlor, J., \& Mulvey, M. (2017). Customer roles in self-service technology encounters in a tourism context. Journal of Travel \& Tourism Marketing, 34(2), 222-238.

[3] Kokkinou, A., \& Cranage, D. A. (2013). Using self-service technology to reduce customer waiting times. International Journal of Hospitality Management, 33, 435-445.

[4] McGrath, C., \& Astell, A. (2017). The benefits and barriers to technology acquisition: Understanding the decision-making processes of older adults with age-related vision loss (ARVL). British Journal of Occupational Therapy, 80(2), 123-131.

[5] Yaacob, S. A., Abdul Aziz, A., Bakhtiar, M. F. S., Othman, Z., Ahmad, N. A. (2021). A Concept of Consumer Acceptance on the usage of Self-Ordering Kiosks at McDonald's. International Journal of Academic Research in Business and Social Sciences, 11(13), 12-20.

[6] Chen Jia Wai. (2016). A Study On The Selection Of Fast Food Restaurant By Utar Kampar Students Using Analytic Hierarchy Process (Ahp). Chen Jia Wai Bachelor Of Science (Hons) Statistical Computing.

[7] Rashid, I. M. A., Sham Abdullah, M. F., Mohd Yusuf, B. N., \& Shaari, M. S. (2014). Impact Of Service And Food Quality On Customer Satisfaction Among Generation Y For The Fast Food Restaurant In Malaysia. Journal Of Social Science Research, 5(2), 784-793. https://doi.org/10.24297/jssr.v5i2.3380

[8] De Voglia, R., Kouvonen, A., \& Gimeno, D. (2014). The influence of market deregulation on fast food consumption and body mass index: A cross-national time series analysis. Bulletin of the World Health Organization, 92(2), 99. https://doi.org/10.2471/BLT.13.120287

[9] Hanie, I., Samah, A., Maizura, I., Rashid, A., Juraij, M., Rani, A., Rahman, A., Ali, M. A., Fazlee, M., \& Abdullah, S. (2015). The Roles Of Price Perception And Physical Environment In Determining Customer Loyalty: Evidence From Fast Food Restaurant Of Malaysia. http://www.journalijdr.com

[10] Statista. (2018) | Malaysia - visited fast food restaurants 2018. https://www.statista.com/statistics/561040/malaysia-visited-fast-fo

[11] McDonald's Reports Fourth Quarter And Full Year 2019 Results And Quarterly Cash Dividend | McDonald's Corporation. (n.d.). Retrieved June 20, 2020, from https://news.mcdonalds.com/news-releases/news $\square$ releasedetails/mcdonalds-reports-fourth-quarter-and-full-year-2019-results-and

[12] Chan, G. S. H., Tang, I. L. F., \& Sou, A. H. K. (2017). An Exploration of Consumer Complaint Behavior towards the Hotel Industry: Case Study in Macao. International Journal of Marketing Studies, 9(5), 56. https://doi.org/10.5539/ijms.v9n5p56

[13] Izzat Zulkifly, M. (2017). Technology readiness, customer perceived value, customer information satisfaction and behavioral intention on tablet-based menu ordering experience / Muhammad Izzat Zulkifly.

[14] Hsu, L., Rd Hsiao-Kang District, S., City, K., \& Pinying Wu, T. (2013). Electronic-Tablet-Based Menu in a Full Service Restaurant and Customer Satisfaction-A Structural Equation Model. In International Journal of Business (Vol. 3, Issue 2). www.ijbhtnet.com

[15] Collier, J. E., Breazeale, M., \& White, A. (2017). Giving back the "self" in self service: customer preferences in self-service failure recovery. Journal of Services Marketing, 31(6), 604-617. https://doi.org/10.1108/JSM $\square 07$ 2016-0259

[16] Chang, Y., Wong, S. F., Sugumar, P. a/p, \& Maruthappa, M. (2015). Determinants of Consumer Intention to Continue Using Table-Top Tablet Ordering Systems in Restaurant Businesses. International Journal of U and eService, Science and Technology, 8(8), 119-128. https://doi.org/10.14257/ijunesst.2015.8.8.13

[17] Advertising Marketing. (2017). McDonald's rolls out self-service kiosks in Malaysia. https://www.marketing $\square$ interactive.com/mcdonalds-rolls-out-self-service-kiosks-in-malaysia

[18] McDonald's Malaysia. (n.d.). McDonald's ${ }^{\circledR}$ Malaysia | Locate Us. Retrieved July 30, 2021, from https://www.mcdonalds.com.my/locate-us

[19] Yang, Q., Goodsir, W., \& Poulston, J. (2019). Automation of the fast-food industry: Gen Z perspectives of self service kiosks versus employee service. Hospitality Insights, 3(2), 7-8. https://doi.org/10.24135/hi.v3i2.66

[20] Leong, C. S. (2019, September 9). McDonald's kiosk ordering system - a UX case study. UX Collective. https://uxdesign.cc/mcdonalds-kiosk-ordering-system-ui-ux-case-study-fe7b3693f12c

[21] Partner story - McDonalds. (n.d.). HUGE. Retrieved July 31, 2021, from https://www.hugeinc.com/work/mcdonalds/

[22] Weijters, B., Rangarajan, D., Falk, T., \& Schillewaert, N. (2007). Determinants and outcomes of customers' use of self-service technology in a retail setting. In Journal of Service Research, 10(1). https://doi.org/10.1177/1094670507302990

[23] Wang, M. C. H. (2012). Determinants and consequences of consumer satisfaction with self-service technology in a retail setting. Managing Service Quality, 22(2), 128-144. https://doi.org/10.1108/09604521211218945 
[24] Chevers, D., \& Spencer, A. (2017). Customer satisfaction in Jamaican hotels through the use of information and communication technology. Worldwide Hospitality and Tourism Themes, 9(1), 70-85. https://doi.org/10.1108/WHATT-11-2016-0068

[25] Eleni. (2019, April 11). Self Service Kiosk | Benefits of Self Service Kiosks | Ergonomic Solutions. https://www.ergonomic.solutions/blog/2019/04/11/the-rise-and-rise-of-self-service-kiosks/

[26] Izzat Zulkifly, M. (2017). Technology readiness, customer perceived value, customer information satisfaction and behavioral intention on tablet-based menu ordering experience / Muhammad Izzat Zulkifly.

[27] Park, C.-H., \& Shin, J.-K. (2017). An exploratory study on the determinants of performance in regional industry technology development programs. Asia Pacific Journal of Innovation and Entrepreneurship, 11(2), 125-143. https://doi.org/10.1108/apjie-08-2017-027

[28] Joo, H. (2017). A Study on Understanding of UI and UX, and Understanding of Design According to User Interface Change. In International Journal of Applied Engineering Research (Vol. 12). http://www.ripublication.com

[29] Kim, S.-J. D.-E. (2016). Technology Trends for UX/UI of Smart Contents. Review of Korea Contents Association, 14(1), 29-33. https://doi.org/10.20924/CCTHBL.2016.14.1.029

[30] Günay, A., \& Erbuł, Ç. (2015). Eliciting positive user experiences with self-service kiosks: Pursuing possibilities. Behaviour and Information Technology, 34(1), 81-93. https://doi.org/10.1080/0144929X.2014.937459

[31] McLean, G., Al-Nabhani, K., \& Wilson, A. (2018). Developing a mobile applications customer experience model (MACE)-implications for retailers. Journal of Business Research, 85, 325-336. https://doi.org/10.1016/j.jbusres.2018.01.018.

[32] Sheng, M. L., \& Teo, T. S. H. (2012). Product attributes and brand equity in the mobile domain: The mediating role of customer experience. International Journal of Information Management, 32(2), 139-146. https://doi.org/10.1016/j.ijinfomgt.2011.11.017.

[33] Schrepp, M., Hinderks, A., \& Thomaschewski, J. (2017). Design and Evaluation of a Short Version of the User Experience Questionnaire (UEQ-S). International Journal of Interactive Multimedia and Artificial Intelligence, 4(6), 103. https://doi.org/10.9781/ijimai.2017.09.001

[34] Feng, L., \& Wei, W. (2019). An empirical study on user experience evaluation and identification of critical UX issues. Sustainability (Switzerland), 11(8). https://doi.org/10.3390/su11082432

[35] Schrepp, M. (2019). User Experience Questionnaire Handbook Version 8. URL: Https:/Www. Researchgate.Net/Publication/303880829_User_Experience_Questionnaire_Handbook_Version_2.(Accessed: 02.02. 2017), September 2015, 1-15. www.ueq-online.org

[36] Hinderks, A., Schrepp, M., \& Thomaschewski, J. (n.d.). User Experience Questionnaire (UEQ). User Experience Questionnaire. Retrieved August 1, 2021, from https://www.ueq-online.org/

[37] Santoso, H. B., Schrepp, M., \& Kartono, R. Y. (2016). Measuring User Experience of the Student-Centered eLearning Environment (Vol. 13). http://sumi.ucc.ie/

[38] Polas, Mohammad. (2018). The Impact of Waiting Time towards Customers Satisfaction in Fast Food Establishments: Evidence from Bangladesh. 10.9790/487X-2005021121.

[39] Pruyn, A., \& Smidts, A. (1998). Effects of waiting on the satisfaction with the service: Beyond objective time measures. International Journal of Research in Marketing, 15(4), 321-334. https://doi.org/10.1016/s01678116(98)00008-1

[40] Chien, S. Y., \& Lin, Y. T. (2014). The Effects of the Service Environment on Perceived Waiting Time and Emotions. Human Factors and Ergonomics in Manufacturing \& Service Industries, 25(3), 319-328. https://doi.org/10.1002/hfm.20542

[41] Munichor, N., \& Rafaeli, A. (2007). Numbers or Apologies? Customer Reactions to Telephone Waiting.

[42] McGuire, K. A., Kimes, S. E., Lynn, M., Lloyd, R. C., \& Pullman, M. E. (2010). A framework for evaluating the customer wait experience. Journal of Service Management, 21(3), 269-290. https://doi.org/10.1108/09564231011050760

[43] Rose, C., \& Nkirina, S. P. (2017). The Relationship Between Perceived Waiting Time Management And Customer Satisfaction Levels Of Commercial Banks In Kenya. International Journal of Innovative Research and Advanced Studies (IJIRAS), 4(9). http://www.ijiras.com/2017/Vol_4-Issue_9/paper_1.pdf

[44] Churchill, G. A., \& Surprenant, C. (1982). An Investigation into the Determinants of Customer Satisfaction. Journal of Marketing Research, 19(4), 491. https://doi.org/10.2307/3151722

[45] John Dudovskiy (2012). Concepts of Customer Services and Customer Satisfaction: Introduction. http://researchmethodology.net/concepts-of-customer-services-and-customer-satisfaction-introduction

[46] Sabir Ghafoor, H. A. \& R. (2014). Factors Affecting Customers Satisfaction in Restaurants Industry in Pakistan OSAMA GHAFOOR MS scholar Comsats institute of information technology Sahiwal. IQRA HAFEEZ. www.irmbrjournal.com

[47] Hong, C., \& Slevitch, L. (2018). Determinants of Customer Satisfaction and Willingness to Use Self-Service Kiosks in the Hotel Industry. Journal of Tourism \& Hospitality, 07(05). https://doi.org/10.4172/21670269.1000379 
[48] Ahmed Audu Maiyaki. (2013). Moderating Effect of Individualism/Collectivism on the Association between Service Quality, Corporate Reputation, Perceived Value and Consumer Behavioural Intention. Journal of Distribution Science, 11(7), 39-45. https://doi.org/10.15722/jds.11.7.201307.39

[49] Zeithaml, V. A., Berry, L. L., \& Parasuraman, A. (1996). The Behavioral Consequences of Service Quality. Journal of Marketing, 60(2), 31. https://doi.org/10.2307/1251929

[50] Lukita, K. A., Galinium, M., \& Purnama, J. (2018). User Experience Analysis of an E-Commerce Website Using User Experience Questionnaire (UEQ) Framework. Seminar Nasional Pakar Ke 1 Tahun 2018, 1, 347-355.

[51] Hair, J. F., Risher, J. J., Sarstedt, M., \& Ringle, C. M. (2019). When to use and how to report the results of PLSSEM. European Business Review, 31(1), 2-24. https://doi.org/10.1108/ebr-11-2018-0203

[52] Hejase, A. J., \& Hejase, H. J. (2014). Confidence in News Media: Exploring Lebanon. May. https://www.researchgate.net/publication/236851021_Confidence_in_New

[53] Mishra, P., Pandey, C. M., Singh, U., Gupta, A., Sahu, C., \& Keshri, A. (2019). Descriptive statistics and normality tests for statistical data. Annals of Cardiac Anaesthesia, 22(1), 67-72. https://doi.org/10.4103/aca.ACA_157_18

[54] Tavakol, M., \& Dennick, R. (2011). Making sense of Cronbach's alpha. International Journal of Medical Education, 2, 53-55. https://doi.org/10.5116/ijme.4dfb.8dfd

[55] Fornell, C.G. and Larcker, D.F. (1981), "Evaluating structural equation models with unobservable variables and measurement error", Journal of Marketing Research, Vol. 18 No. 1, pp. 39-50.

[56] Henseler, J., Ringle, C.M. and Sarstedt, M. (2015), "A new criterion for assessing discriminant validity in variance-based structural equation modeling", Journal of the Academy of Marketing Science, Vol. 43 No. 1, pp. $115-135$.

[57] Hair, J.F., Ringle, C.M. and Sarstedt, M. (2011), “PLS-SEM: indeed a silver bullet”, Journal of Marketing Theory and Practice, Vol. 19 No. 2, pp. 139-151.

[58] Henseler, J., Ringle, C.M. and Sinkovics, R.R. (2009), "The use of partial least squares path modeling in international marketing", in Sinkovics, R.R. and Ghauri, P.N. (Eds) Advances in International Marketing, Emerald, Bingley, pp. 277-320.

[59] Cohen, J. (1988), Statistical Power Analysis for the Behavioral Sciences: Lawrence Erlbaum Associates.

[60] Tenenhaus, M., Amato, S., \& Esposito Vinzi, V. (2004, June). A global goodness-of-fit index for PLS structural equation modelling. In Proceedings of the XLII SIS scientific meeting (Vol. 1, No. 2, pp. 739-742).

[61] Martins, M. A. J., \& Riyanto, S. (2020). The Effect of User Experience on Customer Satisfaction on Netflix Streaming Services in Indonesia. International Journal of Innovative Science and Research Technology, 5(7), 573577. https://doi.org/10.38124/ijisrt20jul545

[62] Davis, M. M., \& Heineke, J. (1998). How disconfirmation, perception and actual waiting times impact customer satisfaction. International Journal of Service Industry Management, 9(1), 64-73. https://doi.org/10.1108/09564239810199950

[63] Bielen, F., \& Demoulin, N. (2007). Waiting time influence on the satisfaction - loyalty relationship in services. Managing Service Quality: An International Journal, 17(2), 174-193. https://doi.org/10.1108/09604520710735182

[64] Chien, S. Y., \& Lin, Y. T. (2015). The effects of the service environment on perceived waiting time and emotions. Human Factors and Ergonomics In Manufacturing, 25(3), 319-328. https://doi.org $/ 10.1002 / \mathrm{hfm} .20542$

[65] Danthanarayana, C. T. (2019). Evaluation of Public Transportation Mode Choice with Passenger Satisfaction: A Case Study of the Semi-Luxury Bus Service on the Panadura-KandyRoute in Sri Lanka. In Journal of the Eastern Asia Society for Transportation Studies (Vol. 13). Eastern Asia Society for Transportation Studies. https://doi.org/10.11175/EASTS.13.1382

[66] Hasan Polas, M. R., Rahman, M. M., Miah, M. A., \& Ali Hayash, M. M. (2018). The Impact of Waiting Time towards Customers' Satisfaction in Fast Food Establishments: Evidence from Bangladesh. IOSR Journal of Business And Management, 20(5), 11-21. https://doi.org/10.9790/487X-2005021121

[67] Djamchid, A. (2003). Do Religions Influence Customer Behavior? Confronting religious rules and marketing concepts. Groupe ESC Dijon Bourgogne, 2-13. https://www.researchgate.net/profile/DjamchidAssadi/publication/242109368_Do_Religions_Influence_Customer_Behavior_Confronting_religious_rules_and_

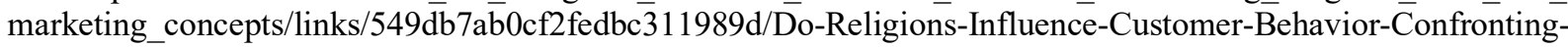
religious-rules-and-marketing-concepts.pdf

[68] Choudhury, K. (2013). Service quality and customers' purchase intentions: An empirical study of the Indian banking sector. International Journal of Bank Marketing, 31(7), 529-543. https://doi.org/10.1108/IJBM-02-20130009

[69] Ghorbanzade, D., Mehrani, H., \& Rahehagh, A. (2019). The effect of experience quality on behavioral intentions of domestic tourists in visiting water parks. Cogent Business and Management, 6(1). https://doi.org/10.1080/23311975.2019.1580843

[70] Wahyuningsih, D. N. (2012). The Effect Of Customer Satisfaction On Behaviorai Intentions A Study On Consumer Behavior Of Car Insurance Consumers In Melbourne, Australia. In International Research Journal of Business Studies (Vol. 3, Issue 1). 